\title{
Post-harvest quality model of pineapple guava fruit according to storage and weather conditions of cultivation
}

\author{
Alfonso Parra-Coronado ${ }^{1}$, Gerhard Fischer ${ }^{2} \&$ Jesús H. Camacho-Tamayo ${ }^{1}$ \\ ${ }^{1}$ Universidad Nacional de Colombia/Facultad de Ingeniería/Departamento de Ingeniería Civil y Agrícola. Bogotá, Colombia. E-mail: aparrac@unal.edu.co \\ (Corresponding author); jhcamachot@unal.edu.co \\ ${ }^{2}$ Universidad Nacional de Colombia/Facultad de Ciencias Agrarias/Departamento de Agronomía. Bogotá, Colombia. E-mail: gfischer@unal.edu.co
}

\section{Key words:}

Acca sellowiana (O. Berg) Burret feijoa

weight loss

soluble solids

firmness

titratable acidity

\begin{abstract}
A B S T R A C T
The post-harvest quality of pineapple guava fruit is determined by the storage and prevailing weather conditions during growth and development. This study proposes a model for postharvest fruit quality according to the storage and weather conditions in the pineapple guava growing region. Physiologically ripe fruit were collected during two harvests from two locations within the Department of Cundinamarca (Colombia): Tenjo and San Francisco de Sales. The fruits were stored at $18 \pm 1{ }^{\circ} \mathrm{C}(76 \pm 5 \%$ relative humidity $(\mathrm{RH})$, over 11 days) and at $5 \pm 1{ }^{\circ} \mathrm{C}(87 \pm 5 \% \mathrm{RH}$, over 31 days $)$, and the quality attributes were evaluated every two days. Models of the most significant physio-chemical quality characteristics of the post-harvest fruit were developed by using the Excel $^{\circledR}$ Solver tool for all data obtained in the two crop periods. The results showed that storage and prevailing weather conditions, which differed according to the altitude of the growing site, had considerable impacts on the physio-chemical characteristics of the fruit throughout the post-harvest ripening process.
\end{abstract}

\author{
Palavras-chave: \\ Acca sellowiana (O. Berg) Burret \\ feijoa \\ perda de peso \\ sólidos solúveis \\ firmeza \\ acidez titulável
}

\section{Modelo da qualidade pós-colheita do fruto da goiaba serrana baseado em condições de armazenamento e climáticas de cultivo}

\begin{abstract}
R E S U M O
A qualidade pós-colheita da goiaba serrana é determinada pelas condições de armazenamento e climáticas durante o crescimento e o desenvolvimento. O objetivo deste estudo foi propor um modelo para a qualidade pós-colheita de frutos de acordo com as condições de armazenamento e climáticas, nas regiões de produção da goiaba serrana. Os frutos foram coletados maduros nas duas safras e em duas localidades do Departamento de Cundinamarca (Colômbia): Tenjo e San Francisco de Sales O fruto foi armazenado por 11 dias a $18 \pm 1{ }^{\circ} \mathrm{C}(76 \pm 5 \%$ de umidade $)$ e por 31 dias a $5 \pm 1{ }^{\circ} \mathrm{C}(87 \pm 5 \%$ de umidade relativa) enquanto os atributos de qualidade foram avaliados a cada dois dias. Modelos das características físico-químicas dos frutos após colheita mais importantes, foram obtidos e utilizado o programa Excel Solver para todos os dados obtidos nos dois períodos de cultivo. Os resultados mostraram que as condições de armazenamento e climáticas da safra, as quais variaram de acordo com a altitude do local de cultivo, tiveram grande impacto sobre os atributos físicos e químicos do fruto, durante o período pós-colheita.
\end{abstract}




\section{INTRODUCTION}

Pineapple guava or feijoa (Acca sellowiana (O. Berg) Burret, Myrtaceae family) is a subtropical shrub that is adapted to the weather conditions of the Colombian Andean region and lives at altitudes ranging from 1,800 to 2,700 m.a.s.l. (Parra-Coronado \& Fischer, 2013). Covering an estimated total production area of $650 \mathrm{ha}$, the pineapple guava crops in Colombia include such varieties as Apollo, Triumph, the clones 8-4 and Quimba, which facilitate pollination and high-quality fruit production (Quintero, 2012).

Pineapple guava fruits exhibit considerable differences in their physio-chemical characteristics during harvest, even among fruit from the same cultivar, and these differences directly affect their post-harvest quality (Parra-Coronado \& Fischer, 2013). The physio-chemical characteristics of fruit are influenced by weather conditions during cultivation and vary depending on altitude, temperature, radiation, precipitation or available soil moisture and relative humidity (Gruda, 2005; Martínez-Vega et al., 2008; Fischer et al., 2012; Galindo et al., 2014).

Variations in quality during the post-harvest period can be quantified using models based on mathematical functions (Corrêa Filho et al., 2015). Using a good model makes it possible to establish relationships between the components that would not be evident if the components were considered separately; a good model can be used to facilitate experiments that are not possible in real systems (Hernández et al., 2009).

This study aimed to develop a model of post-harvest quality in pineapple guava fruit that considers the effects of storage variables (time, temperature and relative humidity $(\mathrm{RH})$ ) and prevailing weather conditions during the pre-harvest period to predict the physio-chemical characteristics during storage.

\section{Materials And Methods}

Pineapple guava fruits were harvested when they reached physiological maturity in two production areas located within the Department of Cundinamarca, Colombia. Clone 41 ('Quimba') trees were planted in these areas in 2006. The first site is located in the Tenjo municipality, with geographic coordinates $4^{\circ} 51^{\prime} 23^{\prime \prime} \mathrm{N}$ and $74^{\circ} 6^{\prime} 33^{\prime \prime} \mathrm{W}$. This site has an average altitude of 2.580 m.a.s.l., a mean temperature of $12.5^{\circ} \mathrm{C}$, a RH between 74 and $86 \%$, a bimodal rainfall pattern, and an average annual precipitation of $765 \mathrm{~mm}$. The second site is located in the San Francisco de Sales municipality, with geographic coordinates $4^{\circ} 57^{\prime} 57^{\prime \prime} \mathrm{N}$ and $74^{\circ} 16^{\prime} 27^{\prime \prime} \mathrm{W}$. This site has an average altitude of 1,800 m.a.s.l., an average temperature of $20.6{ }^{\circ} \mathrm{C}$, a $\mathrm{RH}$ between 63 and $97 \%$, a bimodal rain pattern, and an annual average precipitation of 1,493 $\mathrm{mm}$.
The weather conditions of the study sites from fruit growth and development until harvest (Table 1) were obtained for a two-year period (2012 to 2014). Meteorological data were obtained from weather stations at each sampling site, which provided data on the temperature, $\mathrm{RH}$, precipitation and total radiation on an hourly basis.

Because pineapple guava is a perennial crop, 10 trees per elemental plot and 2 plots per site were used, resulting in a total of 40 trees in this study. The data from one plot for each harvest and farm were used to develop the model, and the data from another plot were used to validate the models. Two harvests were conducted per site, and 300 fruits were collected per plot and per harvest. The fruits that were collected had reached physiological maturity and were free of defects and physical damage. They were collected manually and then transported to the post-harvest laboratory of the Engineering Faculty of the Universidad Nacional de Colombia in Bogota city. The fruits were treated with a $1 \mathrm{~mL} \mathrm{~L}^{-1}$ sodium hypochlorite solution. The fruits were separated according to site of origin and plot and stored at $18 \pm 1{ }^{\circ} \mathrm{C}(76 \pm 5 \% \mathrm{RH}$, over 11 days, 90 fruits $)$ and $5 \pm 1{ }^{\circ} \mathrm{C}(87 \pm 5 \% \mathrm{RH}$, over 31 days, 210 fruits $)$.

The measured quality parameters were soluble solids (SS), titratable acidity (TA), skin and pulp firmness, weight loss (WL) and skin color (hue angle, ${ }^{\circ} \mathrm{h}$ ). The technical standard Norma Técnica Colombiana (NTC) 4624 (ICONTEC, 1999b) was applied when measuring SS with an Eclipse refractometer (Bellingham Stanley, Tunbridge Wells, UK) using a scale from 0 to 32 and a precision of $0.2^{\circ}$ Brix. To determine the TA, the NTC 4623 Technical Standard (ICONTEC, 1999a) was followed: a sample of juice was taken, which was titrated with a solution of $0.1 \mathrm{~N} \mathrm{NaOH}$ to neutralize the acid. To determine the fruit skin and pulp firmness, a Brookfield CT3-4500 texture analyzer (Brookfield Engineering, Middleboro, MA, USA) was used, and two readings per fruit were taken with a TA39 probe at $\pm 0.5 \%$ precision. A gravimetric method (analytical balance "Precisa XT220A", capacity: 220 g, precision: 0.0001 g, Precisa instruments, Switzerland) was used to determine the weight variation during storage; for these measurements, five samples were taken of two fruits each from each storage condition.

The skin color was determined with a Minolta CR-400 colorimeter (Konica Minolta, Ramsey, NJ, USA). The quality parameters were evaluated every 2 days for all fruits under the two storage conditions up to day 11 . The evaluation continued every 4 days for fruits stored at $5{ }^{\circ} \mathrm{C}$ until day 31 . The statistical design was entirely randomized, with five repetitions per trial.

To analyse the variation in quality attributes of the post-harvest pineapple guava fruits, nonlinear polynomial, exponential and sigmoidal models were evaluated as functions of the storage conditions and place of origin (weather conditions) for each of the measured variables during fruit

Table 1. Weather conditions in the studied zones during the growth and development of pineapple guava fruits

\begin{tabular}{|c|c|c|c|c|c|c|c|}
\hline Zone & Harvest & Days $^{1}$ & $\mathrm{GDD}^{2}$ & $\mathrm{~T}^{3}$ & $\begin{array}{l}\mathrm{RH}^{4} \\
(\%)\end{array}$ & $\begin{array}{c}\mathrm{P}^{5} \\
(\mathrm{~mm})\end{array}$ & $\begin{array}{c}\operatorname{Rad}^{6} \\
\left(\mathrm{~W} \mathrm{~m}^{-2}\right)\end{array}$ \\
\hline Tenjo & 1 & 180 & 1,979 & 12.3 & 76.4 & 190 & 12,303 \\
\hline (2,580 m.a.s.I.) & 2 & 180 & 1,966 & 12.3 & 84.3 & 417 & 9,861 \\
\hline San Francisco & 1 & 155 & 2,728 & 18.5 & 86.1 & 573 & 7,814 \\
\hline (1,800 m.a.s.l.) & 2 & 155 & 2,627 & 18.0 & 95.1 & 1,400 & 10,021 \\
\hline
\end{tabular}

${ }^{1}$ Days - Calendar days elapsing from anthesis to harvest; ${ }^{2} \mathrm{GDD}$ - Growing degree days accumulated from anthesis to harvest; ${ }^{3} \mathrm{~T}$ - Mean temperature during the study period; ${ }^{4} \mathrm{RH}$ - Mean relative humidity during the study period; ${ }^{5} \mathrm{P}$ - Accumulated precipitation from anthesis to harvest; ${ }^{6}$ Rad - Accumulated radiation from anthesis to harvest 
storage. The model with the best fit was selected based on having the highest coefficient of determination $\left(\mathrm{R}^{2}\right)$ and lowest standard error. The inputs for each of the variables in the models included information on the storage conditions (number of days, temperature and $\mathrm{RH}$ ) and place of origin (weather conditions of the crop).

The Excel ${ }^{\oplus}$ Solver tool was used for parameter estimation. "Solver is an iterative non-linear procedure, and the first estimation is with the initial values assigned to the parameters in the equation, with those values increasing or decreasing until the lowest value of the sum of the square of the deviations is found" (Parra-Coronado et al., 2015).

The IBM-SPSS statistical package v.20 (Chicago, IL, USA) was used to perform a factor analysis by principal components, and a Varimax rotation was applied to display those variables that had the largest effect on the models. A descriptive statistical analysis was also performed.

Each of the models was evaluated using data that were not used to produce the models. Cross validation between the observed and simulated values was performed to demonstrate that the models provided a good fit to the data. The $\mathrm{R}^{2}$ value, index of concordance (d) and root of the mean squared error (RMSE) were calculated to determine the performance of each of the models (Parra-Coronado et al., 2015).

\section{Results AND Discussion}

An analysis of variance was performed, and it showed that there were significant differences between locations and harvests (Table 2) for the parameter weights, TA and SS. This result indicates that at the time of harvest, those characteristics were strongly influenced by the local weather conditions and the particular harvest conditions (Fischer et al., 2007; Martínez-Vega et al., 2008). Regarding skin firmness, only the second harvest at Tenjo showed significant differences; thus, the effect of weather conditions during crop growth cannot be clearly defined nor used to explain the behavior of this trait at the time of harvest (Kang et al., 2002). Hue angle and pulp firmness did not exhibit significant differences between location and harvest (Table 2), indicating that weather conditions during fruit growth did not affect the values of these physiochemical characteristics at the time of harvest.

The results of an initial multivariate analysis showed that weather variables and storage conditions (temperature and $\mathrm{RH}$ ) had an effect on the physio-chemical characteristics of pineapple guava during the post-harvest period. Altitude $(\mathrm{H})$ was the weather variable with the largest effect $(-0.959)$.

The correlation between climatic variables indicated that for greater $\mathrm{H}$, there would be higher radiation ( $\mathrm{Rad}$ ) and lower GDD, $\mathrm{P}$ and RH. This trend is consistent with the results reported by Fischer et al. (2012), who reported that there is less precipitation and a lower $\mathrm{RH}$ at higher altitude (starting above 1,500 m.a.s.l.). Considering that the weather variable with the greatest effect is $\mathrm{H}$ and that correlations exist between $\mathrm{H}$ and the other weather variables, a second multivariate analysis was performed (Table 3 ) considering only the weather variable $H$, which implicitly correlates the remaining weather variables, to use only those variables with the largest impact on the model.

The results of the principal components analysis when only altitude $(\mathrm{H})$ was included as the weather variable (Table 3 ), corresponding to the second principal component (PC2), explain $26.0 \%$ of the variance and yield the highest commonality values. This result indicates that storage conditions have a strong influence on the development of the models. The effects of $\mathrm{H}$ and $\mathrm{SS}$ are included in the third principal component (PC3), which explains $15.9 \%$ of the variance. The storage period (post-harvest days) and pulp firmness are important variables in the development of the models, and they are included in the first PC, which explains $34.6 \%$ of the variance.

The variables corresponding to weight loss, TA, hue angle and skin firmness did not influence the models. However, weight loss and skin firmness are important quality parameters, and their respective communalities had high values (greater than 0.7), indicating the variability explained by the set of principal components or variance shared by other variables in the factorial analysis; therefore, these variables were considered for the models of variation for post-harvest physico-chemical characteristics.

The correlations between variables (Table 3 ) indicate that as the length of the storage period increases, weight loss and SS increase and TA, hue angle and fruit firmness decrease. These results are consistent with reports by Parra-Coronado \& Fischer (2013) regarding pineapple guava fruits. Those studies indicate that weight loss and SS increase and TA and firmness

Table 3. Multivariate analysis of all of the data from Tenjo and San Francisco considering altitude $(\mathrm{H})$ as the only weather variable

\begin{tabular}{lrrrc}
\hline \multicolumn{1}{c}{ Variable } & \multicolumn{1}{c}{ PC1 } & \multicolumn{1}{c}{ PC2 } & \multicolumn{1}{c}{ PC3 } & Communality \\
Post-harvest days & -0.730 & 0.481 & 0.063 & 0.769 \\
H & 0.076 & 0.047 & -0.936 & 0.884 \\
Storage temperature & 0.010 & -0.975 & -0.039 & 0.953 \\
Storage RH & -0.010 & 0.975 & 0.039 & 0.953 \\
Weight loss & -0.604 & -0.605 & 0.261 & 0.800 \\
SS & -0.264 & -0.101 & -0.848 & 0.800 \\
TA & 0.479 & 0.419 & 0.069 & 0.410 \\
Hue Angle & 0.696 & -0.056 & 0.295 & 0.575 \\
Skin firmness & 0.573 & 0.024 & 0.654 & 0.756 \\
Pulp firmness & 0.772 & 0.197 & 0.349 & 0.757 \\
Eigenvalue & 3.457 & 2.603 & 1.595 & \\
Variance (\%) & 34.575 & 26.033 & 15.945 & \\
Cumulative variance (\%) & 34.575 & 60.608 & 76.553 & \\
\hline *PC1, PC2, PC3: principal components 1, 2 and 3. Values $>0.7$ (absolute value) appear in \\
DCD
\end{tabular}

bold; $\mathrm{H}$ - Altitude; TA - Titratable acidity

Table 2. Mean values ${ }^{1}$ of the physico-chemical characteristics of pineapple guava fruit at the time of harvest

\begin{tabular}{lrrrr}
\hline Parameter & \multicolumn{4}{c}{ Location - Harvest } \\
\cline { 2 - 5 } Fresh weight $(\mathrm{g})$ & Tenj0 -1 & Tenjo -2 & \multicolumn{1}{c}{ San Francisco-1 } & San Francisco-2 \\
SS ( ${ }^{\circ}$ Brix) & $38.23 \pm 4.23 \mathrm{bc}$ & $98.93 \pm 12.62 \mathrm{a}$ & $30.53 \pm 4.67 \mathrm{c}$ & $45.73 \pm 6.83 \mathrm{~b}$ \\
TA (\% citric acid) & $13.35 \pm 0.66 \mathrm{a}$ & $11.73 \pm 0.91 \mathrm{~b}$ & $11.19 \pm 0.81 \mathrm{~b}$ & $11.59 \pm 0.66 \mathrm{~b}$ \\
Hue angle $\left({ }^{\circ} \mathrm{h}\right)$ & $1.91 \pm 0.12 \mathrm{a}$ & $1.68 \pm 0.09 \mathrm{~b}$ & $1.58 \pm 0.07 \mathrm{~b}$ & $1.93 \pm 0.06 \mathrm{a}$ \\
Skin firmness (N) & $124.72 \pm 0.75 \mathrm{a}$ & $123.63 \pm 1.35 \mathrm{a}$ & $121.63 \pm 2.53 \mathrm{a}$ & $124.16 \pm 1.36 \mathrm{a}$ \\
Pulp firmness (N) & $14.82 \pm 3.51 \mathrm{a}$ & $10.21 \pm 2.64 \mathrm{~b}$ & $16.20 \pm 1.30 \mathrm{a}$ & $14.18 \pm 1.87 \mathrm{a}$ \\
\hline
\end{tabular}

${ }_{1}^{1}$ Mean $\pm \mathrm{sd}$; Means followed by different letters for the same parameter indicate significant differences according to Tukey's test ( $\left.p \leq 0.05\right)$ 
decrease during the post-harvest period. Parra-Coronado et al. (2006) reported similar results for pears.

Weight loss during post-harvest ripening is mainly caused by transpiration and respiration, which causes water and substrate loss (Kays \& Paull, 2004). The increase in SS during ripening is caused by organic acids turning into sugars or degrading through respiration (Machado et al., 2015). Loss of firmness during ripening is caused by increased enzymatic activity, which degrades pectins (Parra-Coronado et al., 2006).

The correlations also indicated that at higher storage temperature, weight loss and SS are greater and firmness and TA are lower, which is consistent with the results of Machado et al. (2015), who found that the speed of enzymatic reactions increases exponentially with increasing temperature and is responsible for these physico-chemical changes in orange fruits. Amarante et al. (2008) obtained similar results for pineapple guava, and Parra-Coronado et al. (2006) obtained similar results for pears stored at different temperatures.

The correlations between the variables listed in Table 3 indicate that at higher production zone altitudes, there is a higher SS content and lower values for weight loss and skin and pulp firmness during the post-harvest period. The correlations between weather variables (Table 3 ) indicate that there is greater radiation ( $\mathrm{Rad})$ and lower values for average temperature (GDD), $\mathrm{P}$ and $\mathrm{RH}$ at higher altitudes; these results are consistent with the behavior of SS reported for the Quimba pineapple guava clone (Martínez-Vega et al., 2008), tomato (Gruda, 2005) and other fruits. The results for firmness are consistent with those found for cucumber (Kang et al., 2002).

Based on the results of the multivariate analysis (Table 3 ), polynomial, exponential, and sigmoidal equations were evaluated as functions of the storage conditions and location $(\mathrm{H})$ for each of the physico-chemical characteristics using data from both localities and the Excel Solver tool. A regression analysis was performed to determine the best-fit equations, which corresponded to a quadratic polynomial model in all cases (Eq. 1). Table 4 shows the coefficients used in the equations for different attributes of pineapple guava.

The variables are coefficients defined as follows:

$$
\begin{aligned}
\text { At } & =\left[\mathrm{a} \cdot \mathrm{T}+\mathrm{b} \cdot\left(\frac{1}{\mathrm{RH}}\right)+\mathrm{c} \cdot \mathrm{t}+\mathrm{d} \cdot \mathrm{H}\right]^{2}+ \\
& +\left[\mathrm{e} \cdot \mathrm{T}+\mathrm{f} \cdot\left(\frac{1}{\mathrm{RH}}\right)+\mathrm{g} \cdot \mathrm{t}+\mathrm{h} \cdot \mathrm{H}\right]+\mathrm{i}
\end{aligned}
$$

At - attribute;

WL - weight loss of the fruit, \%;

TA - total titratable acidity, \% citric acid;

SS - total soluble solids, ${ }^{\circ}$ Brix;

SkiFir - skin firmness, $\mathrm{N}$;

PulFir - pulp firmness, $\mathrm{N}$;

hue - color of the epidermis of the fruit; hue angle, ${ }^{\circ} \mathrm{h}$;

a, b, c, d, e, f, g, h, i - coefficients estimated with Solver;

$\mathrm{T} \quad$ - storage temperature, ${ }^{\circ} \mathrm{C}$;

$\mathrm{RH}$ - relative humidity of storage, \%;

$\mathrm{t}$ - time in storage, days; and,

$\mathrm{H} \quad$ - altitude of the production zone, m.a.s.l.

According to the criteria for $\mathrm{R}^{2}$, the model of fruit weight loss provides excellent prediction, whereas the model for SS provides adequate prediction. The models for skin and pulp firmness indicate that the model explains more than $50 \%$ of their variance, whereas the models for TA and skin color have low predictive ability for the post-harvest period.

Figure 1 shows the cross validation of the models, which involved comparing the predicted and observed values during fruit storage (the data used for cross validation were not used for the development of the model). The cross-validation and regression analysis revealed that the model for weight loss has excellent predictive performance; the model for skin firmness indicate that the model explains more than $50 \%$ of their variance, whereas the models for SS and pulp firmness explains less than $50 \%$ of the variance, although these can be still considered useful. The values of the concordance index and RMSE also indicate the good fit of these models for the postharvest period. The models for TA and epidermis color (hue angle) do not adequately estimate these parameters, confirming the results from the multivariate analysis.

The mathematical model for weight loss in the pineapple guava fruit during storage (Eq. 1) could be used as a tool for estimating the maximum storage time in specific conditions so that the fruit exhibits acceptable weight loss, which directly influences the economic yield. Equations for the physico-chemical characteristics of pineapple guava fruits are applicable for storage temperatures between 5 and $18{ }^{\circ} \mathrm{C}$ and for pineapple guava fruits cultivated at altitudes between 1,800 and 2,600 m.a.s.l.

The results presented here have helped to formulate equations that can be used to determine variations in the main physico-chemical characteristics of pineapple guava fruits during the post-harvest period according to storage conditions

\begin{tabular}{|c|c|c|c|c|c|c|}
\hline \multirow{2}{*}{ Coefficients } & \multicolumn{6}{|c|}{ Attributes } \\
\hline & WL & TA & SS & SkiFir & PulFir & hue \\
\hline$a$ & -2.6131 & -2.6973 & -0.7709 & -1.7104 & -2.078 & -2.9739 \\
\hline b & 1492.2892 & 2004.4856 & 302.4858 & 711.0051 & 997.5706 & 2435.8724 \\
\hline c & -0.0242 & 0.000605 & -0.0116 & 0.0176 & 0.0089 & 0.0027 \\
\hline d & 0.000069 & $1.8909 \mathrm{E}-06$ & -0.000011 & 0.000036 & -0.000027 & $-2.61 \mathrm{E}-06$ \\
\hline e & -55.3924 & -30.3962 & -7.5536 & -34.6905 & -45.2278 & -21.850 \\
\hline$f$ & -0.00064 & -0.00064 & -0.00064 & -0.00064 & -0.00064 & -0.00064 \\
\hline $\mathrm{g}$ & 0.3782 & -0.01418 & 0.0289 & -0.1591 & -0.2026 & -0.19716 \\
\hline $\mathrm{h}$ & -0.0021 & -0.00007 & 0.0041 & -0.0065 & -0.0023 & -0.0013 \\
\hline $\mathrm{i}$ & 286.4847 & 86.5955 & 42.1316 & 214.3106 & 252.1828 & 94.41056 \\
\hline $\mathrm{R}^{2\left({ }^{*}\right)}$ & 0.93 & 0,32 & 0.68 & 0.56 & 0.54 & 0.24 \\
\hline St. $E^{(*)}$ & 1.29 & 0.12 & 0.99 & 2.33 & 1.48 & 1.13 \\
\hline
\end{tabular}

Table 4. Coefficients of the equations for different attributes of pineapple guava

WL - weight loss of the fruit, \%; TA - total titratable acidity, \% citric acid; SS - total soluble solids, ${ }^{\circ}$ Brix; SkiFir - skin firmness, N; PulFir - pulp firmness, N; hue - color of the epidermis of the fruit; hue angle, ${ }^{\circ}$. $\mathrm{R}^{2\left(^{*}\right)}$ - Determination coefficient; $\mathrm{St}^{\mathrm{E}^{(*)}}$. - Standard error 


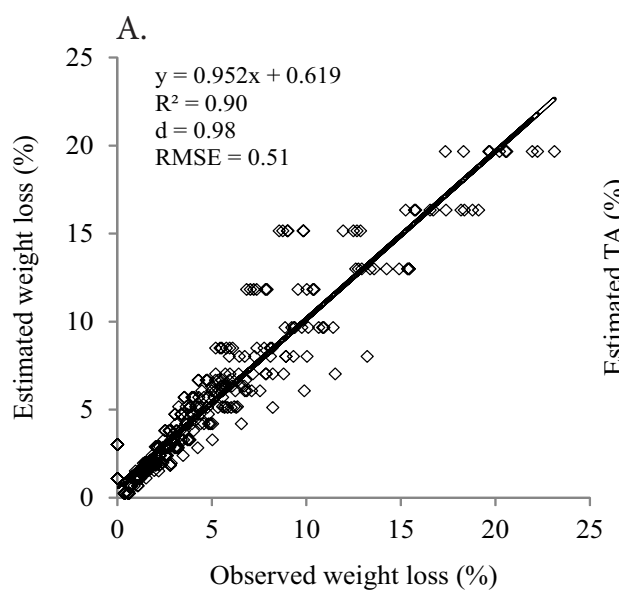

D.

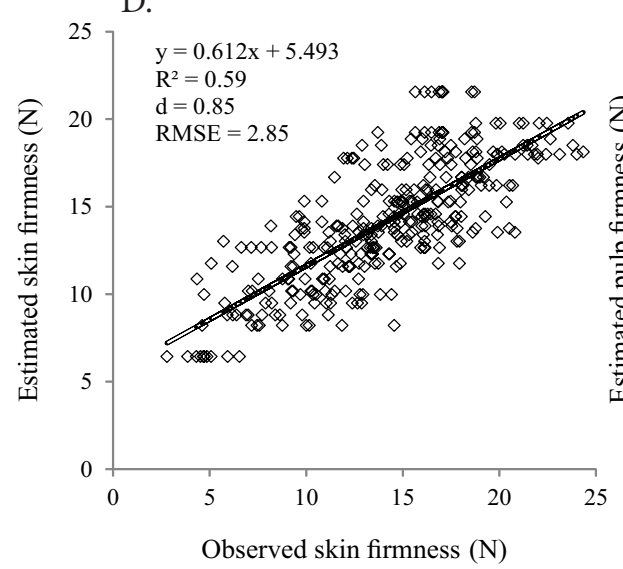

B.

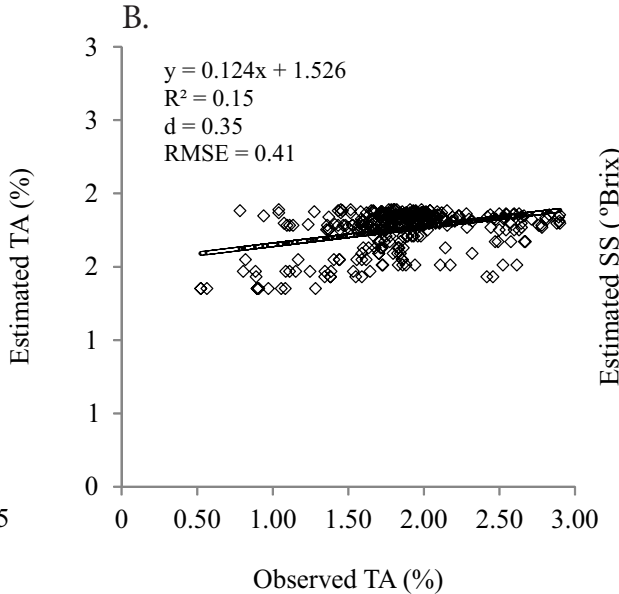

E.

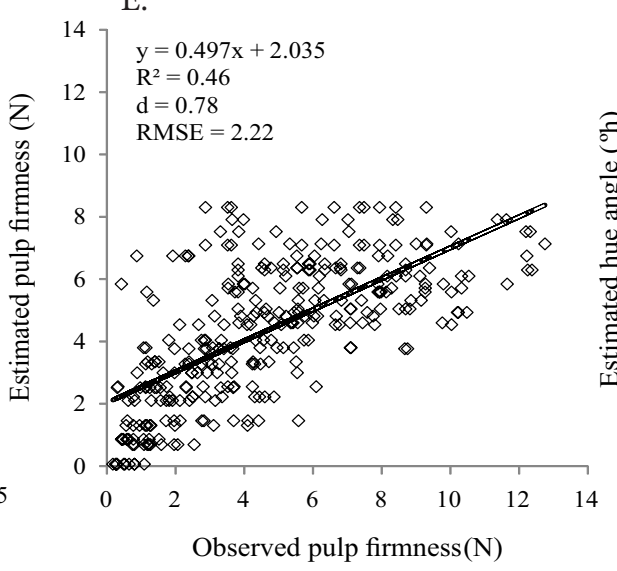

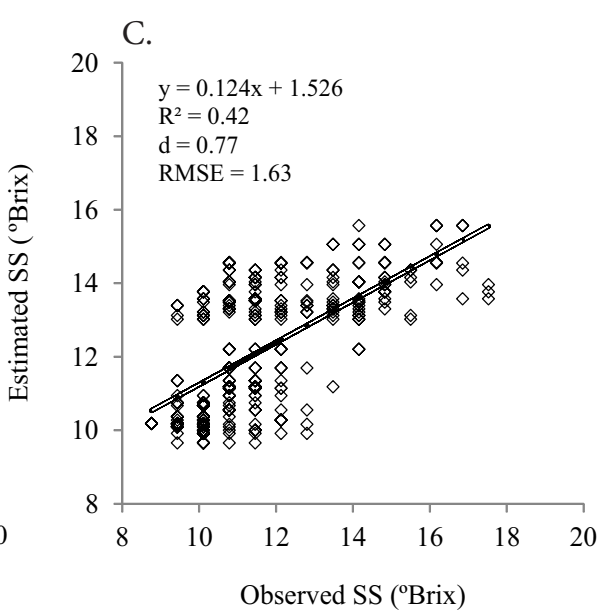

F.

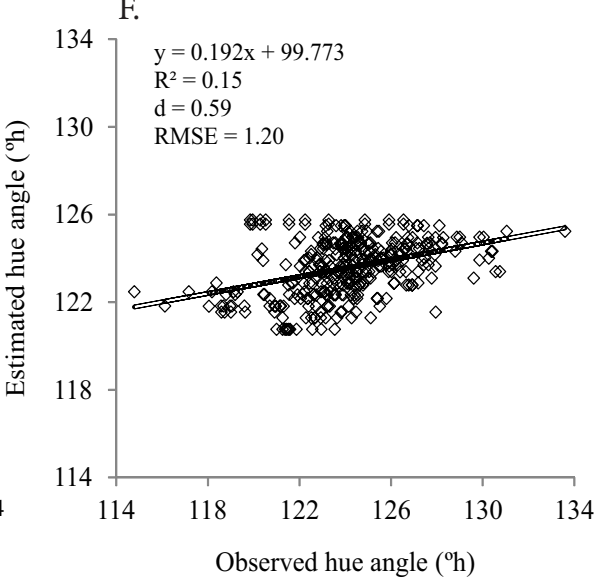

Figure 1. Cross validation of the physico-chemical characteristics of the pineapple guava fruit in the post-harvest period: (A) weight loss model, (B) TA model, (C) SS model, (D) skin firmness model, (E) pulp firmness model, and (F) color model (hue angle)

(number of days, temperature and RH) and prevailing weather conditions during crop growth, which is represented by the altitude of fruit production.

\section{Conclusions}

1. The storage conditions (number of days, temperature, and $\mathrm{RH}$ ) and the prevailing weather conditions during growth, which were represented by the altitude of the fruit production site, strongly influenced the physico-chemical characteristics of pineapple guava fruit during post-harvest ripening.

2. The mathematical models that best predict the changes in post-harvest pineapple guava fruit quality are those for weight loss, SS, and skin and pulp firmness.

3. These models are applicable for storage temperatures between 5 and $18{ }^{\circ} \mathrm{C}$ and for pineapple guava fruits grown at altitudes between 1,800 and 2,600 m.a.s.l. Models for titratable acidity and epidermis color (hue angle) do not adequately estimate these parameters.

\section{Literature Cited}

Amarante, C. V. T. do; Steffens, C. A.; Ducroquet, J. P. H. J.; Sasso, A. Qualidade de goiaba-serrana em resposta à temperatura de armazenamento e ao tratamento com 1-metilciclopropeno. Pesquisa Agropecuária Brasileira, v.43, p.1683-1689, 2008. https:// doi.org/10.1590/S0100-204X2008001200007
Corrêa Filho, L. C.; Andrade, E. T. de; Martinazzo, A. P.; D’Andrea, E. M.; Sousa, F. A. de; Figueira, V. G. Cinética de secagem, contração volumétrica e análise da difusão líquida do figo (Ficus carica L.). Revista Brasileira de Engenharia Agrícola e Ambiental, v.19, p.797-802, 2015. https://doi.org/10.1590/1807-1929/agriambi. v19n8p797-802

Fischer, G.; Ebert, G.; Lüdders, P. Production, seeds and carbohydrate contents of cape gooseberry (Physalis peruviana L.) fruits grown at two contrasting Colombian altitudes. Journal of Applied Botany and Food Quality, v.81, p.29-35, 2007.

Fischer, G.; Ramírez, F.; Almanza-Merchán, P. J. Inducción floral, floración y desarrollo del fruto. In: Fischer G. (ed.). Manual para el cultivo de frutales en el trópico. Bogotá: Produmedios, 2012. Cap.3. p.120-140.

Galindo, A.; Rodríguez, P.; Collado-González, J.; Cruz, Z. N.; Torrecillas, E.; Ondoño, S.; Corell, M.; Moriana, A.; Torrecillas, A. Rainfall intensifies fruit peel cracking in water stressed pomegranate trees. Agricultural and Forest Meteorology, v.194, p.29-35, 2014. https://doi.org/10.1016/j.agrformet.2014.03.015

Gruda, N. Impact of environmental factors on product quality of greenhouse vegetables for fresh consumption. Critical Reviews in Plant Sciences, v.24, p.227-247, 2005. https://doi. org/10.1080/07352680591008628

Hernández, F.; Soto, F.; Caballero, A. Modelos de simulación de cultivos. Características y usos. Cultivos Tropicales, v.30, p.7382, 2009. 
ICONTEC - Instituto Colombiano de Normas Técnicas. Norma técnica colombiana NTC 4623. Productos de frutas y verduras. Determinación de la acidez titulable. Bogotá: Instituto Colombiano de Normas Técnicas y Certificación, 1999a. 6p.

ICONTEC - Instituto Colombiano de Normas Técnicas. Norma técnica colombiana NTC 4624. Jugos de frutas y hortalizas. Determinación del contenido de sólidos solubles. Método refractométrico. Bogotá: Instituto Colombiano de Normas Técnicas y Certificación, 1999b. 9p.

Kang, H. M.; Park, K. W.; Saltveit, M. E. Elevated growing temperatures during the day improve the postharvest chilling tolerance of greenhouse-grown cucumber (Cucumis sativus) fruit. Postharvest Biology and Technology, v.24, p.49-57, 2002. https:// doi.org/10.1016/S0925-5214(01)00129-6

Kays, S. J.; Paull, R. E. Postharvest biology. Athens: Exxon Press, 2004. 568p.

Machado, F. L. de C.; Cajazeira, J. P.; Costa, J. M. C. da. Color change and quality response of 'lane late' orange submitted to degreening process. Engenharia Agrícola, v.35, p.144-153, 2015. https://doi. org/10.1590/1809-4430-Eng.Agric.v35n1p144-153/2015
Martínez-Vega, R. R.; Fischer, G.; Herrera, A.; Chaves, B.; Quintero, O. C. Características físico-químicas de frutos de feijoa influenciadas por la posición en el canopi. Revista Colombiana de Ciencias Hortícolas, v.2, p.21-32, 2008. https://doi.org/10.17584/rcch.2008v2i1.1170

Parra-Coronado, A.; Fischer, G. Maduración y comportamiento poscosecha de la feijoa (Acca sellowiana (O. Berg) Burret). Una revisión. Revista Colombiana de Ciencias Hortícolas, v.7, p.98-11, 2013. https://doi.org/10.17584/rcch.2013v7i1.2039

Parra-Coronado, A.; Fischer, G.; Chaves-Córdoba, B. Tiempo térmico para estados fenológicos reproductivos de la feijoa (Acca sellowiana (O. Berg) Burret). Acta Biológica Colombiana, v.20, p.167-177, 2015.

Parra-Coronado, A.; Hernández, J. E. H.; Camacho-Tamayo, J. H. Estudio de algunas propiedades físicas y fisiológicas precosecha de la pera variedad Triunfo de Viena. Revista Brasileira de Fruticultura, v.28, p.55-59, 2006. https://doi.org/10.1590/S010029452006000100017

Quintero, O. C. Feijoa (Acca sellowiana Berg). In: Fischer, G. (ed.). Manual para el cultivo de frutales en el trópico. Bogotá: Produmedios, 2012. Cap.4, p.443-473. 